\title{
WATAK ASBAB AN-NUZUL DALAM PENDIDIKAN ISLAM
}

\author{
Fitriani Nur Alifah \\ Universitas Islam Negeri Sunan Kalijaga Yogyakarta \\ Alifahnurfitriani15@gmail.com
}

\begin{abstract}
Abstrak
Asbab An-Nuzul merupakan Ilmu untuk mengetahui adanya sebab dan peristiwa mengenai latar belakang suatu ayat atau beberapa ayat yang diturunkan oleh Allah Swt, yaitu ayat alQur'an yang berupa perkataan Allah Swt. Al-Qur'an di turunkan melalui perantara malaikat jibril yang diwahyukan kepada Nabi Muhammad Saw. Asbab an-Nuzul bertujuan untuk menjelaskan hikmah tentang persyariatan terhadap hukum dan untuk mengkhususkan hukum yang bersifat umum. al-Qur'an merupakan sebuah landasan khusus atau sebuah rujukan bagi pedoman masyarakat Islam, dengan memahami makna Asbab An-Nuzul, masyarakat akan lebih bisa menambah wawasan dan pemahaman tentang sejarah alQur'an, disamping itu masayarakat akan lebih memahami asal usul ayat-ayat yang diturunkan, dalam hal ini seseorang yang memahami Watak Asbab An-Nuzul seseorang akan tahu bagaimana mengaplikasikan dan merealisasikan dalam kehidupan sehari-hari serta meneladaninya. Pendidikan Islam juga mengkaji tentang hal Asbab an-Nuzul, karena dalam memahami ayatayat alQur'an tersebut ada yang dapat difahami langsung dan ada yang membutuhkan penjelasan, oleh karena itu sebelum memahami tentang pendidikan Islam perlu mempelajari tentang karakter atau watak dari Asbab an-Nuzul terlebih dahulu.
\end{abstract}

Kata kunci: Watak, Asbabun an-Nuそul, Pendidikan Islam.

\begin{abstract}
Asbab An-Nuzul is a science to know the existence of causes and events concerning the background of a verse or several verses revealed by Allah, namely the verse of the Qur'an in the form of Allah's words. The Qur'an was revealed through the intermediary of the angel Gabriel revealed to the Prophet Mubammad. Asbab an-Nuzul aims to explain the wisdom of the provisions of the law and to specialize laws that are general in nature. al-Qur'an is a special foundation or a reference for Islamic community guidelines, by understanding the meaning of Asbab An-Nuzul, the community will be more able to add insight and understanding of the bistory of the Qur'an, besides that the community will better understand the origin of the verses revealed, in this case someone who understands the character of Asbab An-Nuгul someone will know how to apply and realize in everyday life and imitate him. Islamic education also examines the issue of Asbab an-Nuzul, because in understanding the verses of the Qur'an there are things that can be understood directly and some need explanations, therefore before understanding about Islamic education it is necessary to learn about the character or character of Asbab-an Nuzul first.
\end{abstract}

Keywords: Character, Asbabun an-Nuzul, Islamic Education.

Nazhruna: Jurnal Pendidikan Islam

Vol. 2 No 1 2019. Issn: 2614-8013. Hal. 28-44

DOI: $10.31538 /$ nzh.v2i1.170 


\section{Pendahuluan}

Al-Qur'an adalah kalam Allah yang menjadi sumber utama bagi manusia sebagai petunjuk dan pedoman hidup manusia muslim di dunia yang bertujuan untuk mencapai kehidupan yang lebih baik lagi. Baik kehidupan di dunia maupun di akhirat, salah satu pesan-pesan dari ayat al-Qur'an yakni melalui Asbab An-Nuzul. ${ }^{1}$

Konsep sejarah dalam Asbab An-Nuzul ini terkumpul dari riwayatriwayat yang terpilih dimana konsep tersebut menggambarkan turunnya ayat al-Quran itu dari konsep sejarah itu sendiri. Asbab An-Nu₹ul ini menjelaskan bagaimana sebab-sebab turunnya ayat al-Qur'an melalui wahyu yang diturunkan oleh malaikat jibril dan disampaikan kepada Nabi Muhammad Saw, baik satu ayat, maupun satu surat. Pernyataan tersebut itu muncul yang diungkapkan oleh ahli sejarah Qur'an maupun sejaran Agama Islam.

Masalah lafadz atau makna yang mungkin terdapat ayat-ayat yang kurang jelas, untuk mencari kejelasan yang ada adalah dengan cara mencari tahu bagaimana latar belakang turunnya ayat tersebut dengan sebab suatu peristiwa yang terjadi, sehingga dapat memahami dan memperoleh makna ayat tersebut secara jelas dan sempurna. Makan dengan itu Asbab An-Nuzul ini dianggap penting oleh sebagian ulama, karena dengan Asbab An-Nuqul akan mudah memahami dan mengurangi rasa keraguan untuk menafsirkan ayat al-Qur'an dengan baik dan benar.

Untuk menfsirkan sebuah ayat al-Qur'an, banyak cara dan metode yang dapat digunakan, misalnya menggunakan Ilmu I'rab al-Qur'an ${ }^{2}$, Ilmu Gharib', Ilmu Awqat an Nuzul ${ }^{4}$, dan Ilmu Azbab an Nuzul ${ }^{5}$. Dalam beberapa kategori

1 Kafrawi Ridwan (ed.), et, al., Ensiklopedi Islam (Jakarta: PT. Ichtiar Baru Van Hoeve, 2002), hlm. 132.

${ }^{2}$ Yaitu ilmu yang menguraikan fungsi dan posisi kata dalam susunan kalimat AlQur'an.

3 Yaitu ilmu yang menjelaskan makna kata-kata yang ganjil, yang tidak umum digunakan dalam pergaulan sehari-hari, dan makna kata-kata yang bernilai sastra tinggi.

4 Yaitu ilmu yang membicarakan waktu-waktu turunya ayat. Misalnya, ayat-ayat yang diturunkan di siang hari di sebut nahariyyah, ayat-ayat yang diturunkan pada malam hari di sebut lailiyyah, ayat-ayat yang diturunkan di musim panas di sebut shafiyyah, dan ayat-ayat yang diturunkan di musim dingin disebut syita'iyyah.

5 Yaitu ilmu yang berfungsi mengungkaplan kejadian-kejadian historis serta peristiwa-peristiwa yang melatarbelakangi turunya nash al-Qur'an. 
tersebut ada salah satu metode yang sangat penting dan biasa digunakan untuk memahami isi dan tafsir al-Qur'an oleh para Ulama yakni Ilmu Azbab an Nuzul, dengan hal ini sudah diketahui bahwa al-Qur'an itu diturunkan dengan dua cara, yang pertama diturunkan langsung tanpa berangsur-angsur melalui malaikat jibril , kemudian yang kedua al-Qur'an diturunkan ketika mengalami sebuah peristiwa yang telah terjadi berasarkan turunnya wahyu Allah, dalam hal ini yang akan dibahas oleh penulis mengenai bagaimana sebab da nasal muasalnya diturunkan ayat al-Qur'an yakni Asbab An-Nu₹ul sesuai dengan nash-nash yang ada. ${ }^{6}$

Para pakar Tafsir Ilmu al-Qur'an diantaranya adalah seorang Guru dari Imam Bukhari, al-wahidi, al-ja'bari, Ibn Hajar, dan Asy-syuyuthi, yakni yang bernama Ali bin Madini, beliau adalah salah satu tokoh yang terkenal dengan meneliti tafsir al-Qur'an dengan menggunakan pemahamannya melalui $A s b \bar{\alpha} b$ an-Nuгül. ${ }^{7}$

Manusia dalam menentukan sesuatu hal adalah tidak hanya asal menentukan, salah satunya adalah menentukan sebuah hukum, karenanya untuk mempelajari atau memahami ilmu $A s b \bar{\alpha} b$ an-Nuzül ini sangat penting bagi seorang muslim, agar tahu bagaiman asal sebab turunnya ayat al-Qur'an untuk memahami suatu kandungan ayat al-Qur'an yang akan difahaminya. ${ }^{8}$ Makan dengan itu al-Qur'an diciptakan oleh Allah sudah jelas kadarnya bahwa untuk menunjukkan kepada manusia sebagai pedoman hidupnya gara tahu jalan mana yang baik dan benar untuk ditempuh, hal ini senantiasa manusia agar berlandaskan kehidupan sesuai dengan risalah-risalah dengan menguatkan keimanannya manusia itu sendiri kepada Allah Swt.

Dalam setiap kejadian $A s b \bar{\alpha} b$ an-Nuথ̄ull selalu berkaitan dengan kisahkisah sahabat Nabi, karena itu peristiwa $A s b \bar{\alpha} b$ an-Nuzūl ini sangat bermanfat bagi penafsir al-Qur'an, dalam pengetahuan $A s b \bar{\alpha} b$ an-Nuг̌ul ada 2 sighat yang berbeda. ${ }^{9}$ yakni pertama Sharihah dan mumtamalah ${ }^{10}$. Maka dengan itu kisah

${ }^{6}$ Yusuf al-Qardawi, Bagaimana Berinteraksi dengan Al-Qur'an, Terj. Kathur Suhardi (Jakarta: Pustaka al-Kausar, 2000), h. 267.

7 Manna' Khalil al-Qaththan, “Studi Imu-ilmu Qur'an”, Terj. Drs. Mudzakir AS, (Bogor: Pustaka Litera Nusantara, 1992), h. 106.

8 Didin Saefudin Buchori, "Pedoman Memahami Kandungan Al-Qur'an", (Bogor: Granada Pustaka, 2005), h.34-35.

${ }^{9}$ Yunahar Ilyas, Kuliah Ulumul Qur'an, (Yogyakarta: ITQAN Publishing: 2015), hlm. 124. 


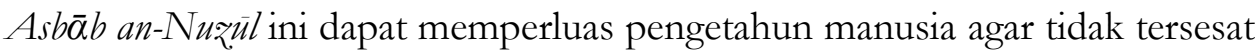
dalam menerima sebuah pemahaman yang ada.

\section{Pembahasan}

\section{Makna Asbabun Nuzul}

Asbāb an-Nuð̄ūl dalam segi bahasa arab adalah أسباب النزول yang berarti sebab turunya suatu ayat, sedangkan menurut Kamus Besar Bahasa Indonesia adalah sebab berarti suatu hal karena adanya asal sesuatu ${ }^{11}$, Nuzul berarti turun yang artinya sesuau yang bergerak dari atas ke bawah dari tempat asalnya. ${ }^{12}$

Maka makna $A s b \bar{\alpha} b$ an-Nuðūl dari segi terminologis adalah sebab-sebab turunnya suatu ayat al-Qur'an baik menjelaskan status hukum asalnya dalam berupa pernyataan ataupun peristowa $A s b \bar{\alpha} b$ an-Nu₹ūl yang ada, dan itu senantiasa dipelajari dalam Ilmu al-Qur'an. Sehingga bagi Mussafir akan memudahkan untuk menemukan dan menafsirkan suatu ayat al-Qur'an yang dilihat dalam hikmah peristiwa $A s b \bar{\alpha} b$ an-Nu₹̄ul itu sendiri. ${ }^{13}$

Asbāb an-Nu₹zull ditinjau dalam ilmu Nahwu yakni yang berarti dalam kiasan Istilah idafa (اضافة), dalam peristiwa-peristiwa tersebut bisa juga diambil dalam peristiwa Nabi atau pernyataan Nabi itu sendiri. ${ }^{14}$

Dari beberapa pengertian $A s b \bar{\alpha} b$ an-Nuzūl dilihat menurut pendapat beberapa Ulama adalah :

\section{Menurut Al Zarqani}

Yang dinamakan $A s b \bar{\alpha} b$ an-Nu₹ūl adalah kehkhususan dalam suatu hal yang menjelaskan bagaimana turunnya sebuah ayat al-Qur'an, untuk

10 Sharihah merupakan Sighat atau redaksi yang digunakan perawi secara tegas dan jelas menunjukan asbabun nuzul. Mumtamalah merupakan Sighat atau redaksi yang digunakan perawi tidak secara tegas dan jelas menunjukan asbabun nuzul.

11 Tim Penyusun Kamus Besar Indonesia, Departemen Pendidikan dan Kebudayaan, Kamus Besar Indonesia, (Jakarta: Balai Pustaka, 1990), h. 790.

12 Kamus Besar Bahasa Indonesia..,. h. 976.

13 Diakses pada tanggal 20 oktober 2017 pada pukul 00.41 WIB https://id.wikipedia.org/wiki/Asbabun Nuzul.

${ }^{14}$ Yunahar Ilyas, Kuliah Ulumul Qur'an, Op.Cit., hlm. 120. 
penjelas suatu hukum saat terjadi peristiwa $A s b \bar{\alpha} b$ an-Nuqūl itu terjadi. $^{15}$

\section{Al- Shabuni}

Asbāb an-Nuqūl adalah sebuah peristiwa yang menjadikan sebuah ayat-ayat al-Qur'an yang mulia, yang berkaitan dengan kejadiankejadian pada saat itu, baik pernyataan yang dinyatakan oleh Nabi, ataupun suatu kejadian yang berhubungan atas urusan Agama itu sendiri. ${ }^{16}$

\section{Shubhi Shalih}

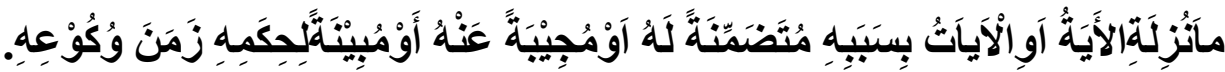

Asbāb an-Nurūl yakni suatu hal yang menggambarkan sebuah perisiwa yang menkadkan sebab turunnya sebuah ayat al-Qur'an sebagai penjelas suatu hukum peristiwa yang terjadi. ${ }^{17}$

\section{Mana' Al-Qatthan}

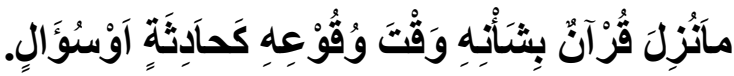

Asbōb an-Nuzūl adalah sebuah peristiwa yang menjadikan diturunkannya al-Qur'an, berdasarkan saat peristiwa-peristiwa itu terjadi, dengan peristiwa tersebut dengan pernyataan yang ditujukan kepada Nabi.

\section{Nurcholis Majid}

Mengatakan bahwa $A s b \bar{\alpha} b$ an-Nuzūl adalah sebuah konsep yang menjadikan sebab diturunkan wahyu Allah dari al-Qur'an kepada Nabi Muhammad Saw, baik diturunkan satu atau rangkaian ayat, bahkan satu surat.

Demikian pada pengertian yang telah dijelaskan oleh beberapa tokoh diatas walaupun berbeda namun pada intinya semua definisi diatas dapat disimplkan bahwa Asbōb an-Nuqūl adalah sebuah peristiwa yang menjadikan ayat al-Qur'an itu diturunkan sebagai penjelas dan menjawab permasalahan-permasalahan yang ada di dunia ini, dan

15 Muhammad Abdul Al-'Azhim Al-Zarqani, "Manahil Al Irafan fi Ulumul Qur'an, Beirut: t.t, jilid I, h.106.

${ }^{16}$ Muhammad Ali Al-Shabuni, At Tibbayan fi Ulumul Quran, Maktabah Al Ghazali, Damaskus, 1390, h. 22.

${ }_{17}$ Subhi Shalih, Mabahis fi Ulum Al-Quran, Dar Al Qalam li Al Malayyin, Beirut, 1988, h.132. 
turunnya sebuah ayat $A s b \bar{\alpha} b$ an-Nurūl ini juga bertujuan untuk memahami sejarah bagi manusia agar lebih bisa memahami perintahperintah Allah Swt, dengan begitu peristiwa ini hanya terlingkup saat diturunkannya ayat al-Qur'an itu saja (ashr at-tanzid). ${ }^{18}$

\section{Metode Mengetahui Asbabun Nuzul}

Asbāb an-Nuqūl merupakan suatu peristiwa yang tidak hanya sekedar ungkapan pristiwa untuk diberitakan kepada umat manusia melainkan untuk mengetahui bagaimana sebuah peristiwa $A s b \bar{\alpha} b$ anNu₹ūl ini juga dilandasakan berdasarkan hadist Nabi Muhammad Saw sesuai Keshabihannya, berikut hadist yang dinyatakan $A l$-Wabidi :

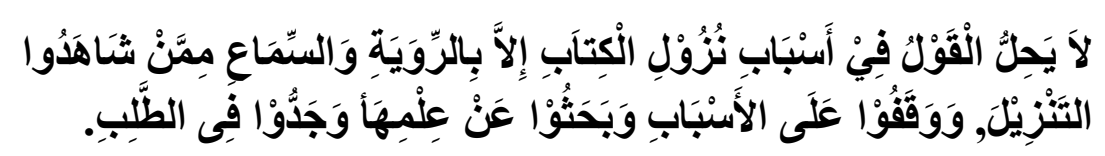

Yang artinya : "Tidak boleh berpendapat mengenai Asbabun Nuqul Kecuali dengan berdasarkan kepada riwayat atau mendengar langsung dari orang-orang yang menyaksikan turunya, mengetahui sebab-sebabnya dan membahas tentang pengertiannya dan bersungguh-sungguh dalam mencarinya". ${ }^{19}$

\section{Macam-macam Asbabun Nuzul}

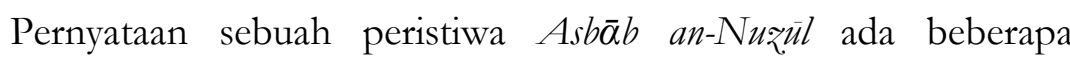
konsep dan aspek yang harus diketahui terlebih dahulu untuk memahami konteks $A s b \bar{\alpha} b$ an-Nuqūl itu sendiri, diantaranya adalah :

1. Dalam hadist yang dipilih harus tahu dalam sudut pandang kejelasannya. $^{20}$ dari segi riwayatnya ataupun lainnya, ditinjau dari segi perawi $A s b \bar{\alpha} b$ an-Nuzūl ada yang Jelas atau Visionable (Sharib), dan kemungkinan atau Impossible (mumtamilab).

Dapat dikatakan sebuah pernyataan yang Sharih yakni apabila perawi menyatakan :

Artinya: "Sebab turun ayat ini adalah...

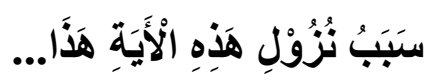

${ }^{18}$ Rosihon Anwar, Ulumul Quran (Bandung: Pustaka Setia, 2006), hal. 61.

19 Al-Hafizh Jalal ad-Din 'Abd ar-Rahman as-Suyuthi, Al-Itqan fi 'Ulum Al-Qur'an, (Beirut: al-Maktabah al-'Ashiriyah, 2003), juz 1, hlm. 89.

${ }^{20}$ Rosihon Anwar, ULUM AL-QUR'AN, (Bandung, CV PUSTAKA SETIA, 2015), hlm. 67. 
Kemudian yang kedua apabila sebuah pernyataan itu menggunakan kata "maka", seperti :

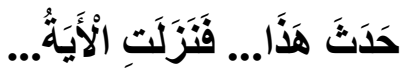

Artinya: Telab terjadi.. maka turunlah ayat ini...

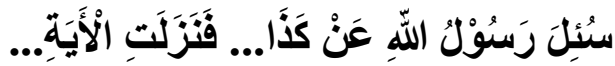

Artinya: Rasulullah pernah ditanya tentang... maka turunlab ayat... kemudian ciri-ciri yang digunakan dalam pernyataan mumtamilah yakni apabila perawi menyatakan :

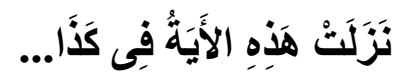

Artinya: "Ayat ini turun berkenaan dengan.."

Artinya: "Saya kira ayat ini turun berkenaan dengan..."

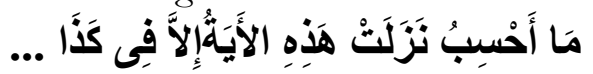

2. Melihat pernyataan $A s b \bar{\alpha} b$ an-Nuqūl dari segi sudut pandangnya, ada dua sudut pandang yang berbeda yang digunakan dalam menyatakan sebuah peristiwa $A s b \bar{\alpha} b$ an-Nuz̄ul, yang pertama yakni ditinjau dari sebuah peristiwa (baditsah / waqiah), kemudian yang kedua yakni berdasarkan sebuah pernyataan (su'al), adanya kedua bentuk tersebut karena diturunkan sebuah ayat al-Qur'an itu adalah sebuah jawaban sebagai penjelas kejadian atau peristiwa tertentu yang telah terjadi.

Ditinjau dari segi peristiwa ada beberapa bentuk $A s b \bar{\alpha} b$ an-Nuzūl, diantaranya yaitu :

a. Adanya suatu peristiwa karena terjadi konflik, seperti peristiwa anttara Khazraj dan Suku Aus yang menimbulkan suatu konflik adanya fitnah yang dilakukakn oleh kaum Yahudi, maka dari itu turunlah sebuah ayat QS. Ali Imran: 101, yang berbunyi :

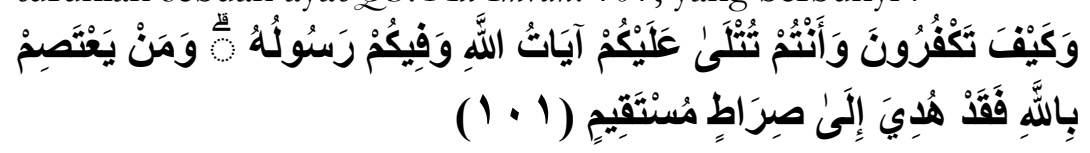

Artinya: "Bagaimana kamu kafir, padahal dibacakan kepadamu ayatayat Allah (Al-qur'an) dan Rasul-Nya pun berada ditengah-tengah kamu. 
Barang siapa yang berpegang teguh kepada Allah, maka sesunggubnya ia telab diberi petunjuk kepada jalan yang benar." ${ }^{21}$ (QS. Ali Imran: 101).

b. Adanya peristiwa yang menggambarkan sebuah kesalahan vatal, misalnya saat ada Imam Masjid yang membacakan salah satu Surah itu tdak benar, dikarena orang yang membacakannya sedang mabuk, maka turunlah sebuah ayat QS. an-Nisa': 43:

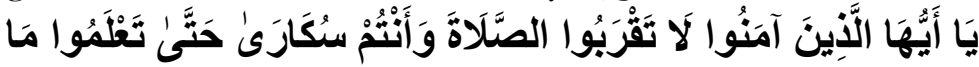

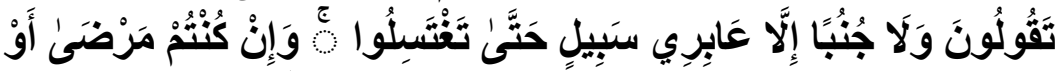

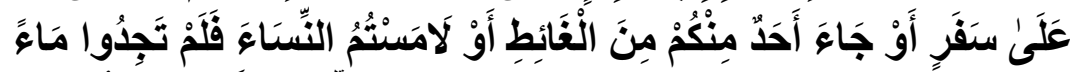

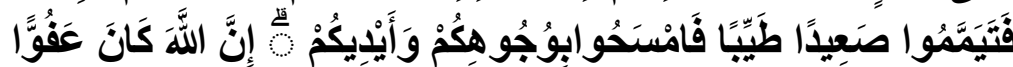

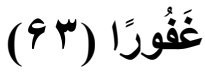

Artinya: Hai orang-orang yang beriman, janganlah kamu shalat, sedang kamu dalam Keadaan mabuk, sebingga kamu mengerti apa yang kamu ucapkan, (jangan pula hampiri mesjid) sedang kamu dalam Keadaan junub, terkecuali sekedar berlalu saja, hingga kamu mandi. dan jikea kamu sakit atau sedang dalam musafir atau datang dari tempat buang air atau kamu telah menyentuh perempuan, kemudian kamu tidak mendapat air, Maka bertayamumlab kamu dengan tanah yang baik (suci); sapulah mukamu dan tanganmu. Sesungguhnya Allah Maha Pema'af lagi Maha Pengampun. ${ }^{22}$ (QS. an-Nisa': 43).

c. Sebuah peristiwa yang berupa keinginan (cita-cita), seperti suatu hal yang diinginkan Umar bin Khattab yang ingin menjadikan sebuah makam Nabi Ibrahim untuk menjadikan sebagai tempat Ibadah, yakni tempat shalat, maka terjadilah turun suatu ayat Q.S Al-Baqarah:125:

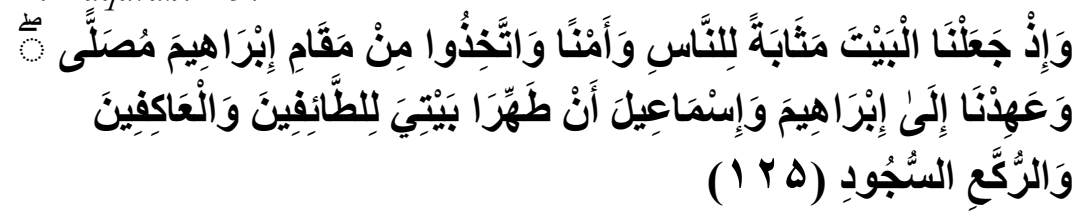

Artinya: Dan (ingatlah), ketika Kami menjadikan rumah itu (Baitullab) tempat berkumpul bagi manusia dan tempat yang aman. Dan jadikanlah sebahagian maqam Ibrahim tempat shalat. Dan telah Kami perintabkan kepada Ibrahim dan Ismail: "Bersibkanlah rumab-Ku untuk orang-orang

${ }^{21}$ https://tafsirq.com/topik/Ali+Imran+ayat+101

22 https://tafsirq.com/topik/an-Nisa+ayat +43 
yang thawaf, yang i'tikaf, yang ruku' dan yang sujud"23. (Q.S AlBaqarah:125).

Pernyataan Asbab al-Nuzul yang berupa pernyataan yakni, menggambarkan sebuah pernyataan yang telah terjadi, seperti penyataan bagaimana Roh itu, seraya dinyatakan oeh kaum yahudi kepada Nabi Muhammag Saw, mka untuk menjawab permasalahan tersebut turunlah sebuah ayat $Q s$ Al-Isra ayat 85:

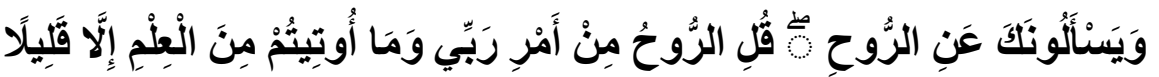

Artinya: Dan mereka bertanya kepadamu tentang roh. Katakanlah: "Roh itu termasuk urusan Tuban-ku, dan tidaklah kamu diberi pengetabuan melainkan sedikit". (Q.S Al-Isra':85). ${ }^{24}$

3. Pernyataan sebuah asbab an-nuzul yakni harus mengetahui dari aspek jumlah sebab dan ayat yang akan diturunkan, sehingga akan tau satu persatu untuk mengatasi sebuah permasalahan yang ada, asbab annuzul dapat dijelaskan dengan :

\section{a. Ta'addud Al-Asbab Wa Al-Nazil Wahid ${ }^{25}$}

Yakni sebab diturunkannya sebuah ayat untuk menangani beberapa sebab tentang peristiwa yang terjadi, maka turunlah sebuah ayat dari Q.S. Al-Ikblas: 1-4, ${ }^{26}$

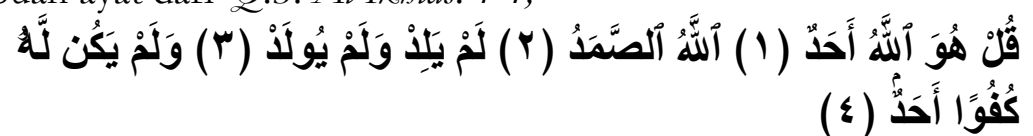

Artinya: Katakanlab:'Dia-lah Allah, yang maha Esa. Allah adalah tuban yang bergantung kepada-Nya segala sesuatu. Tiada berada beranak dan tiada pula di peranakkan. Dan tiada seoarangpun yang setara dengan dengan dia.

${ }^{23}$ https:/ / tafsirq.com/topik/Al-Baqarah+ayat125

24 https://tafsirq.com/topik/Al-Isra+ayat+85

25 Yaitu: apabila riwayat tentang sebab turun ayat lebih dari satu, tetapi yang turun hanya satu (ayat, kelompok ayat atau satu surat).

${ }^{26}$ Muhammad Ali Ash-shaabuuniy, At-Tibyaan Fii Uluumil Qur'an, Alih Bahasa oleh Aminuddin, Studi Ilmu al-Qur'an (Bandung: Pustaka Setia, 1998), hal. 52. 


\section{b. Ta'adud An-Nazil Wa Al-asbab Wahid"7}

Ada satu sebab yang menggambarkan turunnya sebuah ayat alQur'an yakni turunnya sebuah ayat Q.S. Ad-dukhan: 10,15 dan16:

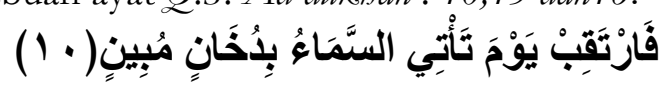

Artinya: "Maka tunggulah hari ketika langit membawa kabut yang nyata, ”

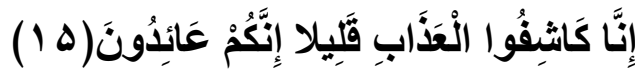
Artinya: "Sesunggubnya (kalau) kami akan melenyapkan siksaan itu agak sedikit sesunggubnya kamu akan kembali (ingkar)".

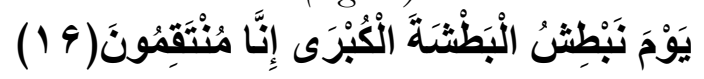

Artinya : "(ingatlah) hari (ketika) kami menghantam mereka dengan bantaman yang keras. Sesunggubnya kami memberi balasan".

\section{Urgensi Asbab an-Nuzul Dalam Memahami Makna al-Qur'an}

Manusia muslim memiliki keunggulan tersendiri untuk mengetahui dan memahami bagaimana sebuah peristiwa Asbab an-Nuqul, karena pada saat itu memahami sebuah peristiwa $A s b a b$ an-Nuzul adalah penting bagi masyarakat arab untuk memecahkan suatu permasalahan yang ada saat itu, wilayah arab saat itu berasumsi bahwa pemahaman setiap ayat-ayat yang diturunkan adalah mengandung sebab dan akibat yang khusus namun perlu banyak pertimbangan dalam menafsirkan maupun merealisasikannya, mkaa dengan itu pemahaman Asbab anNuəul ini menjadi penting bagi masyarakat muslim itu sendiri.28

Konteks Asbab an-Nu₹ul merupakan suatu proses penurunan ayat al-Qur'an yang diturunkan kepada Nabi Muhammad Saw dan merupakan tanggapan khusus dari Allah Swt bagi keadaan masyarakat arab saat itu. Misalnya digambarkan dalam keadaan masyarakat arab saat itu yang berprinsip bahwa Tuhan itu adalah berhala-berhala besar, sehingga masyarakat saat itu menyembahnya selain menyembah Allah

${ }^{27}$ Yaitu banyak ayat yang turun, padahal sebabnya satu, artinya banyak ayat yang diturunkan diberbagai surat mengenai suatu peristiwa. Contohnya surat Ali 'Imran 195, AnNisa' 32, dan Al-Ahzab 33 turun dengan satu sebab, yaitu pertanyaan Ummu Salamah RA kepada Rasulullah SAW.

28 Ali Shadiqin, "Antrropologi al-Qur'an : Model Dialektika Wabyu dan Budaya", (Yogyakarta: Ar-Ruzz Media, 2008), h. 184-185. 
Swt, maka tidak lain dari suatu peristiwa tersebut turunlah ayat-ayat alQur'an tentang Akidah, sehingga dapat dilihat bahwa memang turunya sebuah ayat al-Qur'an tidak lain tanpa adanya $A s b a b$ an-Nuzul. ${ }^{29}$

Dari beberapa peristiwa diturunkannya ayat-ayat al-Qur'an, tidak lain adalah tujuan utamanya memang untuk memecahkan sebuah permasalahan yang ada saat itu, namu seiring berjalannya waktu sahabat dan Rasulullah Saw malah mengetahui beberapa peristiwa lainnya yang telah terjadi, seperti peristiwa-peristiwa sejarah, baik itu peristiwa yang di alami oleh sahabat dan Rasulullah maupun bukan, sehingga dengan semakin banyaknya sebuah peristiwa yang ada maka perlu adanya penjelasan khusus tentang Hukum Allah, kemudian bertanyalah sahabat kepada Rasulullah mengenai hal itu, dengan begitu turunlah ayat berikutnya sebagai penjelas dari peristiwa yang ada dan sebuah pernyataan yang dilontarkan kepada Nabi Muhammad Saw. ${ }^{30}$

Pentingnya untuk mengetahui dan mempelajari Asbab an-Nuqul dalam memahami ayat-ayat al-Qur'an yakni diuraikan dalam ayat $Q \boldsymbol{s}$. alMa'idah (5) ayat 93:

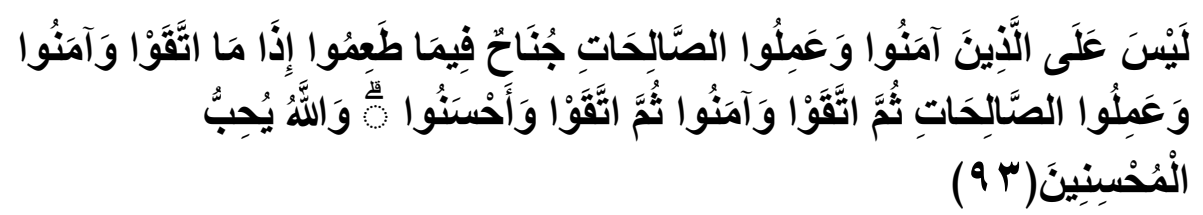

Artinya :

Tidak ada dosa bagi orang-orang yang beriman dan mengerjakan amalan yang shaleh karena memakan makanan yang telah mereka makan dabulu, apabila mereka bertakwa serta beriman, dan mengerjakan amalan-amalan yang shaleh, kemudian mereka tetap bertakwa dan beriman, kemudian mereka (tetap juga) bertakwa dan berbuat kebajikan. Dan Allah menyukai orang-orang yang berbuat kebajikan. (Q.S Al-Maidab:93).

Jika dilihat dari pemaparan Qs. al-Maidah : 93 diatas maka seseorang akan berpendapat untuk boleh memakan makanan apa saja, asalkan manusia itu sendiri masih berimana dan beramal Sholeh. Namun ada penjelasan oleh Ustman bin Ma'zun dan juga Umar bin Ma'adi Karb bahwa Khamr itu dihukumkan mubah, namun sudah jelas pernyataan terebut bertentangan dengan Qs. al-Maidah : 3, yang berbunyi bahwa

${ }^{29}$ Kadar M. Yusuf, Studi Al-Qur'an (Jakarta:Amzah, 2009), hal. 90.

${ }^{30}$ Abid Rohman. M. Fil. I, Studi al-Qur'an (Surabaya: IAIN SA Press, 2011), h. 166. 
setiap muslim haram dan mutlak untuk memakan daging babi, darah, bangkai, khamr, dsb.

Pernyataan ayat terseut tidaklah berlaku pada masyarakat muslim saat itu, karena meminum khamr dianggapnya tidak ada larangan Karena itupun sebelum turunya ayat al-Qur'an Qs. al-Maidah : 3, sehingga tidak adanya pelarangan maupun hukum berdosa untuk meminumnya, namun lambat laun, setelah turunnya ayat tersebut, maka Allah menghukumi khamr adalah rajsun yakni perbuatan setan, sehingga turunlah ayat tersebut untuk memperjelas sebuah hukum peristiwa saat itu.

Pentingnya untuk mempelajari dan memahami Asbab an-Nu₹ul, dikemukakan oleh Az-Zarqani dalam beberapa point nya, yakni sebagai berikut :

1) Untuk menjawab segala keraguan dala ketidakpastian dalam memahami sebuah ayat-ayat al-Qur'an.

2) Menunjukkan pelaku yang pasti bagaimana sebuah ayat al-Qur'an itu diturunkan.

3) Menjelaskan sebuah hukum yang khusus yang ada di dlaam alQur'an.

4) Meyakinkan kepada mausia bahwa al-Qur'an adalah benar kalam ciptaan Allah, bukanlah sebuah buatan manusia yang ada.

5) Memantapkan manusia untuk meyakini wahyu Allah dan juga mempermudah untuk mendengar dan juga menghafal serta memahami ayat-ayat al-Qur'an.

6) Manusia akan memahami rahasia-rahasia Allah ada di dalam alQur'an.

7) Menunjukkan bahwa Allah lah yang memberi pengertian khusus kepada Rasulullah untuk menjalankan sebuah tujuan Rasulullah.

8) Manusia akan mengetahui bagaimana ayat tersebut tersirat dalam ayat khusu ataupun umum, sehingga dapat mengetahui sebelum direalisasikan.

9) Dapat mengetahui suatu hukum syariat dengan jelas. 


\section{Manfaat Mengetahui Asbabun Nuzul}

Setelah mengetahui pentingnya memahami Asbab an-Nuzul, berikut ada banyak manfaat juga untuk mempelajari dan memahami Asbab an-Nuqul, diantaranya adalah :

1) Seseorang akan mengetahui suatu peristiwa yang menjadikan suatu hukum, dan itu juga bisa berlaku dikemudian hari apabila terjadi sebuah peristiwa yang sama terjadinya dengan peristiwa sebelumnya.

2) Dalam menetapkan suatu hukum, akan mengetahui sebuah hikmah yang ada, bahwa pemberlakuan hukum tersebut termasuk untuk kemaslahatan umat dan merupakan rahmat dari Allah Swt. ${ }^{31}$

3) Dengan adanya Asbab an-Nuzul akan menunjukkan sebuah lafadz ayat yang mungkin bersifat umum dan itu akan menunjukkan dalildalil yang menunjukkan kekhususannya, dan itu hanya berupa bentu bagaimana sebabnya.

4) Turunnya sebuah ayat yang ada akan menunjukkan kepada siapa tujuan ayat al-Qur'an itu diturunkan dan bertujuan untuk apa, sehingga tidak ada unsur penurunan ayat al-Qur'an untuk diaplikan kepada seseorang dalam peranan sebuah permusuhan ataupun perselisihan.

5) Menjelaskan sebab diturunkannya ayat al-Qur'an dengan melihat peristiwa-peristiwa yang terjadi, sehingga dapat menjelaskan satu hal yang bermanfaat bagi orang lain untk menjawab tantangan permasalahan yang ada. ${ }^{32}$

6) Dapat mengetahui hukum-hukum yang khusus walaupun lafadzlafadz tersebut bersifat umum dan itu berkaitan dengan Asbab anNuzul.

7) Seseorang akan mendapatkan tameng untuk sesuatu yang rumit (Isykal), seperti yang dijelasakan sebagai berikut :

a. Al-Wahidi : beranggapan bahwa turunnya sebuah ayat itu tidak mungkin tanpa adanya kisah-kisah yang terjadi untuk menafsirkan sebuah ayat tersebut.

31 Imam Jalaluddin As-Suyutti, Studi Al-Qur'an Komperhenshif, (Surakarta: Indiva Pustaka, 2008), hal 124.

32 Subhi As-Shalih, Menbahas Ilmu-Imu Al-Qur'an (Jakarta: Pustaka Firdaus, 1996), hal 157. 
b. Ibnu Daqiq al-'Id : bahwa untuk mengetahui dan memahami sebuah kisah Asbab an-Nuzul yakni sebuah cara yang paling efktif dalam pemahaman sebuah makna al-Qur'an.

c. Ibnu Taimiyyah : seseorang yang mempelajari tentang Asbab anNuzul akan dapat membantu seseorang untuk memahami bagaimana makna sebuah ayat, karena menurut Ibnu Taimiyah, memahami sesuatu yang telah terjadi itu akan meninggalkan satu hal Ilmu musabab.

d. Maran bin Hakam dalam peristiwanya saat itu yakni ketika beliau merasa terbelit dengan hal sulit untuk memahami sebuah ayat dalam Firman Allah Swt Qs. ali Imran: 188, yang berbunyi :

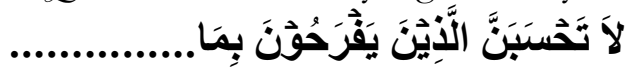

Kemudian Maran bin Hakam mengatakan apabila seeorang itu merasa senang karena dia dipuji kemudian ia merasa senang tanpa melakukan sebuah hal apa yang telah dipuji dan itu sebagai rasa siksaan, niscaya dia akan merasa selalu tersisksa.

Adanya peristiwa tersebut maka Ibnu Abbas memaparkan penjelasannya kepada Maran bin Hakam, bahwa turunnya sebuah ayat tersebut diturunkannya untuk ahlul kitabnya, kemudian Nabi Muhammad Saw bertanya bahwa menyembunyikan sesuatu lalu diperlihatkannya sesuatu itu kepada orang lain, kemudian diceritakannya dan diperlihatkan lagi kepada yang lainnya dengan sesuatu yang telah ditanyakannya oleh Nabi Muhammad Saw, dan mereka mintalah untuk dipuji dengan demikian itu. (HR. Bukhari Muslim).

8) Akan membantu seorang Mussfair untuk memahami ayat yang mungkin itu sulit untuk ditafsirkan maupun difahaminya tanpa adanya peristiwa asbab al-nu₹ul, karena demikian itu terkadang sesuatu akan terjadi sesuai dengan peristiwa yang dialami orang itu sendiri. $^{33}$

Imam Ibnu Daqiq al-cied (wafat 702 H.), mengatakan bahwa mengetahui sebuah peristiwa asbab al-nu₹ul itu salah satu jalan yang menguatkan untuk pemahaman dari sebuah makna ayat al-Qur'an.

${ }^{33}$ Imam Jalaluddin As-Suyutti,loc.Cit., 
Seperti Contoh yang difirmankan Allah Swt dalam QS. Al-Baqoroh, ayat: 158 :

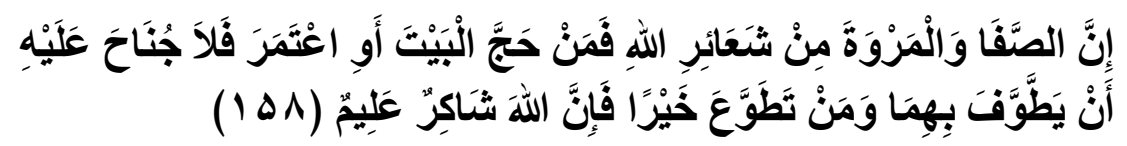

Artinya: "Sesungguhnya Safa dan Marwa adalah sebagian dari syi'ar Allah. Maka barang siapa beribadah haji ke Baitullah atau berumrah,maka tidake. ada dosa baginya untuk mengerjakan sa'i di antara keduanya. Dan barang siapa mengerjakan suatu kebajikan dengan kerelaan hati, maka sesungguhnya Allab Maha Mensyukuri kebaikan dan Maha Mengetabui."

Dari penjelasan ayat diatas menyatakan bahwa sa'i itu hukumnya wajib, karena tidak adanya sebab dosa untuk mngerjakannya sa'i tersebut itu menunjukkan sebuah "kebolehan" melainkan bukan sebuah "kewajiban" lagi, endapat tersebut juga diutarakan oleh beberapa ulama yang memandang arti penjelasan terkstual ayat tersebut. ${ }^{34}$

Adanya penuran ayat tersebut, maka akan lebih mudah untuk memahami sebuah makna ayat tersebut, namun para ulama berpendapat bahwa seseorang yang kesulitan dalam memaknai sebuah ayat al-Qur'an dalam hal perbedaan penafsirannya, maka terlebih dahulu untuk mengetahui bagaimana tafsir al-Qur'an tersebut sesuai dengan sabab al-nuzul sharib-sharib. ${ }^{35}$

Banyaknya manfaat yang telah dijelaskan dalam hal-hal yang memahami kisah Asbab al-Nuzul itu sendiri sudah jelas bahwa tujuan utamanya adalah memudahkan para Mufassir untuk memudahkan dalam menafsirkan dan memaknai sebuah ayat al-Qur'an, dan juga dapat mengambil dari sebuah hikmah dari sebuah hukum yang ditetapkan sesuai dengan hikmah kisah atau peristiwa asbab al-nuzul yang diturunkannya suatu ayat al-Qur'an, begitu jugayang di paparkan oleh Ibnu Taimiyah tentang bagaimana manfaat memahami sebuah asbab al-nu₹ul, maka jelaslah asbab al-nuгul

34

http://myrealblo.blogspot.co.id/2015/11/ulumul-quran-ilmu-asbabun-

nuzul.html

${ }^{35}$ Husain bin Ali bin Husain al-Harbiy, Qowaid at-Tarjih, (Riyadh: Dar al-Qasim, 1996) hal. 241 
memberikan pemahaman yang kokoh terhadap pemahaman sebuah penafsiran ayat al-Qur'an itu sendiri. ${ }^{36}$

\section{Kesimpulan}

Asb $\bar{\alpha} b$ an-Nuথūl adalah sebuah peristiwa yang menggambarkan bagaimana diturunkannya suatu ayat al-Qur'an yang bertujuan untuk menjawab sebuah peristiwa-peristiwa yang ada untuk menjawab pernyataan-pernyataan yang menjadikan sebuah hukum masyarakat arab pada saat itu, dan juga memiliki manfaat yang sangat besar bagi seseorang yang mempelajarinya, yakni salah satunya bagi Musafir untuk menafsirkan atau memaknai sebuah ayat al-Qur'an sehingga tidak ada keraguan lagi untuk memaknainya, karena sebuah hukum tersebut diambil dari sebuah kisah-kisah Nabi atau pernyataan Nabi pada saat peristiwa itu terjadi.

Dalam pemahaman kisah Asbab al-Nuzul ini juga dapat dipaparkan kepada peserta didik, bagaimana kisah-kisah terdahulu dapat menjadi tauladan bagi peserta didik itu sendiri, sehingga kisah-kisah tersebut dapat membangkitkan semangat siswa untuk lebih memahami sejarah-sejarah Islam sendiri.

Aspek yang menggambarkan kisah Asbab al-Nuzul itu terbagi sendiri dalam pembahasan diatas, yakni Asbab al-Nuzul ditinjau dari sei peristiwa dan pernyataan, dan juga dapat dilihat melalui jumlah sebab ayat itu diturunkan yakni dengan Ta'addud al-sabab wa al-nazil wahid dan Ta'adud al-nazil wa al-sabab wahid.

Maka dengan itu pentingnya untuk memahami peristiwa $A s b a b$ al-Nu₹ul adalah bertujuan untuk lebih bisa memahami ayat-ayat alQur'an dengan sumber yang terpercaya tanpa ada keraguan sedikitpun, karena Asbab al-Nu₹ul ini juga para ulama menjadikan sebuah acuan bahkan ada dalam penyusunannya dengan cara yang khusus, karena beranggapan begitu pentingnya kisah Asbab al-Nuгul it sendiri, maka dengan itu kita sebagai umat muslim pun harus tau bagaimana kisah Asbab al-Nuqul itu sendiri tanpa harus meragukan untuk mempelajari dan mengajarkannya kepada peserta didik.

36 A. Mudjab Mahali, Asbabun Nuzul: Studi Pendalaman Al-Qur'an, (Jakarta: PT. Raja Grafindo Persada, 2002), h. 634-635. 


\section{Referensi}

al-Qardawi Yusuf, Bagaimana Berinteraksi dengan Al-Qur'an, Terj. Kathur Suhardi (Jakarta: Pustaka al-Kausar, 2000).

al-Qaththan Manna' Khalil, “Studi Ilmu-ilmu Qur'an”, Terj. Drs. Mudzakir AS, (Bogor: Pustaka Litera Nusantara, 1992).

Anwar Rosihon, Ulumul Quran (Bandung: Pustaka Setia, 2006).

Anwar Rosihon, Ulumul Quran (Bandung: Pustaka Setia, 2006).

Ash-shaabuuniy Muhammad Ali, At-Tibyaan Fii Uluumil Qur'an, Alih

Bahasa oleh Aminuddin, Studi Ilmu al-Qur'an (Bandung: Pustaka Setia, 1998).

As-Shalih Subhi, Menbahas Ilmu-Ilmu Al-Qur'an (Jakarta: Pustaka Firdaus, 1996).

As-Suyutti Imam Jalaluddin, Studi Al-Qur'an Komperhenshif,(Surakarta: Indiva Pustaka, 2008).

Buchori Didin Saefudin, 'Pedoman Memahami Kandungan Al-Qur'an', (Bogor: Granada Pustaka, 2005).

Husain bin Ali bin Husain al-Harbiy, Qowaid at-Tarjih, (Riyadh: Dar alQasim, 1996).

Ilyas Yunahar, Kuliah Ulumul Qur'an, (Yogyakarta: ITQAN Publishing: 2015).

M Yusuf Kadar., Studi Al-Qur'an (Jakarta:Amzah, 2009).

Mahali A. Mudjab, Asbabun Nurul: Studi Pendalaman Al-Qur'an, Jakarta: PT. Raja Grafindo Persada, 2002).

Muhammad Abdul Al-'Azhim Al-Zarqani, "Manabil Al Irafan fi Ulumul Qur'an, Beirut: t.t, jilid I.

Muhammad Ali Al-Shabuni, At Tibbayan fi Ulumul Quran, Maktabah Al Ghazali, Damaskus, 1390.

Ridwan Kafrawi (ed.), et, al., Ensiklopedi Islam (Jakarta: PT. Ichtiar Baru Van Hoeve, 2002).

Rohman Abid M. Fil. I, Studi al-Qur'an (Surabaya: IAIN SA Press, 2011). Shadiqin Ali, "Antrropologi al-Qur'an : Model Dialektika Wabyu dan Budaya", (Yogyakarta: Ar-Ruzz Media, 2008).

Shalih Subhi, Mabahis fi Ulum Al-Quran, Dar Al Qalam li Al Malayyin, Beirut, 1988. 